\section{Halothane decreases calcium sensitivity of rat aortic smooth muscle}

Masahiro Kakuyama MD, Kumi Nakamura MD, Kenjiro Mori MD FRCA

Purpose: To examine the effect of halothane on the cytosolic $\mathrm{Ca}^{2+}$ concentration $\left(\left[\mathrm{Ca}^{2+}\right]_{i}\right)$-tension relationship of rat aortic smooth muscle.

Methods: Rat aortic rings without endothelia were loaded with the fluorescent $\mathrm{Ca}^{2+}$ indicator, Fura PE3-AM, and then mounted in organ baths. The changes in isometric tension and $\left[\mathrm{Ca}^{2+}\right]_{i}$ were measured simultaneously. In one series ionomycin ( $10 \mathrm{nM}-3 \mu \mathrm{M}$ ) was added to normal Krebs' solution cumulatively in the absence and presence of halothane $(1.5 \%, 3 \%)$. In the other series, $\mathrm{CaCl}_{2}(0.3-3 \mathrm{mM})$ was added to $\mathrm{Ca}^{2+}$-free Krebs' solution including high $\mathrm{KCl}(50 \mathrm{mM})$, phenylephrine $(100 \mathrm{nM})$ or prostaglandin $\mathrm{F}_{2 \alpha}\left(\mathrm{PGF}_{2 \alpha}, 1-3 \mu \mathrm{M}\right)$ in the absence and presence of halothane $(1.5 \%, 3 \%)$. The linear part of $\left[\mathrm{Ca}^{2+}\right]_{i}$-tension relationship was analyzed by a linear regression.

Results: Halothane, $1.5 \%$, had no effect on the normal $\left[\mathrm{Ca}^{2+}\right]_{\mathrm{i}}$-tension relationship obtained with the calcium ionophore, ionomycin ( $10 \mathrm{nM}-3 \mu \mathrm{M})$, but halothane $3 \%$ decreased the slope of the relationship $(0.239 \pm 0.037$ for control and $0.110 \pm 0.010$ for halothane $3 \%, P<0.05)$. Halothane, $1.5 \%$ and $3 \%$, did not change the $\left[\mathrm{Ca}^{2+}\right]_{i}$-tension relationship obtained with $\mathrm{CaCl}_{2}(0.3-3 \mathrm{mM})$ in the presence of high $\mathrm{KCl}(50 \mathrm{mM})$ or phenylephrine $(100 \mathrm{nM})$. In contrast, halothane, $3 \%$, inhibited the intercept of $\left[\mathrm{Ca}^{2+}\right]_{i}$-tension relationship obtained with $\mathrm{CaCl}_{2}(0.3-3 \mathrm{mM})$ in the presence of prostaglandin $\mathrm{F}_{2 \alpha}\left(\mathrm{PGF}_{2 \alpha^{\prime}} 1-3 \mu \mathrm{M}\right)(45.708 \pm 4.233$ for control and 26.997 \pm 2.522 for halothane $3 \%, P<0.01$ ).

Conclusion: Halothane decreases the $\mathrm{Ca}^{2+}$ sensitivity and that in the presence of $\mathrm{PGF}_{2}$.

Objectif : Étudier l'effet de l'halothane sur la relation tension isométrique-concentration calcique cytosolique $\left(\left[\mathrm{Ca}^{2+}\right]_{\text {; }}\right)$ sur le muscle lisse de l'aorte chez le rat.

Méthode : Des anneaux aortiques de rat, sans endothélium, ont été chargés avec un indicateur de fluorescence pour le $\mathrm{Ca}^{2+}$, le Fura PE3-AM, et montés ensuite dans des bains d'organes. Les changements de tension isométrique et de $\left[\mathrm{Ca}^{2+}\right]_{i}$ ont été mesurés simultanément. Dans une série, on a ajouté de l'ionomycine ( 10 nM$3 \mu \mathrm{M})$ à la solution Krebs normale, de façon cumulée en l'absence et en présence d'halothane (1,5\%, $3 \%)$. Dans l'autre série, du $\mathrm{CaCl}_{2}(0,3-3 \mathrm{mM})$ a été ajouté à la solution Krebs libre de $\mathrm{Ca}^{2+}$ incluant une forte concentration de $\mathrm{KCl}(50 \mathrm{mM})$, de phényléphrine $(100 \mathrm{nM})$ ou de prostaglandine $F_{2}\left(\mathrm{PGF}_{2}, 1-3 \mu \mathrm{M}\right)$ en l'absence et en présence d'halothane $(\mathrm{I}, 5 \%, 3 \%)$. La portion linéaire de la relation $\left[\mathrm{Ca}^{2+}\right]_{\mathrm{i}}$-tension a été analysée par une régression linéaire.

Résultats : L'halothane, 1,5\%, n'a pas eu d'effet sur la relation $\left[\mathrm{Ca}^{2+}\right]_{i}$-tension isométrique normale obtenue avec l'ionophore calcique (ionomycine $10 \mathrm{nM}-3 \mu \mathrm{M}$ ), mais l'halothane $3 \%$ a fait baisser la pente de la relation $(0,239 \pm 0,037$ pour les témoins et $0,110 \pm 0,010$ pour l'halothane $3 \%, P<0,05)$. Lhalothane, $1,5 \%$ et $3 \%$, n'a pas changé la relation [ $\left.\mathrm{Ca}^{2+}\right]_{i}$-tension obtenue avec le $\mathrm{CaCl}_{2}(0,3-3 \mathrm{mM})$ en présence d'une forte concentration de $\mathrm{KCl}(50 \mathrm{mM})$ ou de phényléphrine (100 nM). Par ailleurs, l'halothane $3 \%$ modifie à la baisse l'ordonnée à l'origine de la relation $\left[\mathrm{Ca}^{2+}\right]_{i}$-tension obtenue avec le $\mathrm{CaCl}_{2}(0,3-3 \mathrm{mM})$ en présence de prostaglandine $F_{2}$ $\left(\mathrm{PGF}_{2}, \mathrm{l}-3 \mu \mathrm{M}\right)(45,708 \pm 4,233$ pour les témoins et $26,997 \pm 2,522$ pour l'halothane $3 \%, P<0,01)$.

Conclusion : L'halothane diminue la sensibilité du $\mathrm{Ca}^{2+}$ et ce, en présence de la PGF 2 .

From the Department of Anesthesia, Kyoto University Hospital, Kyoto 606-8507, Japan. Address correspondence to: Masahiro Kakuyama MD, Department of Anesthesia, Kyoto University Hospital, Kyoto 606-8507, Japan. Phone: +81-75-751-3435; Fax: +81-75-751-3575; E-mail: kakuyama@kuhp.kyoto-u.ac.jp

Accepted for publication August 22, 1999 
$\mathrm{H}$ ALOTHANE is a potent direct vasodilator ${ }^{1,2}$ and, combined with a cardiac suppressive effect, influences organ blood flow. In some organs such as the brain, liver and uterus, blood flow is well maintained during halothane anesthesia because decrease in the regional vascular resistance compensates for the reduced cardiac output. ${ }^{3,4}$ Vasodilatation in the brain also causes an increase in intracranial pressure. In the lung, halothane inhibits hypoxic vasoconstriction induced by hypoventilation or atelectasis and may increase intrapulmonary shunt. ${ }^{5}$ Thus, the vasodilating effect of halothane has important clinical implications. However, the mechanisms by which halothane induces direct vasodilatation is not fully understood.

Contraction of vascular smooth muscle is regulated by the cytosolic $\mathrm{Ca}^{2+}$ concentration $\left(\left[\mathrm{Ca}^{2+}\right]_{\mathrm{i}}\right)$ and the sensitivity of contractile elements to $\left[\mathrm{Ca}^{2+}\right]_{\mathrm{i}}\left(\mathrm{Ca}^{2+}\right.$ sensitivity). $\mathrm{Ca}^{2+}$ sensitivity can be expressed as relationship between $\left[\mathrm{Ca}^{2+}\right]_{i}$ and tension. Recently, a $\mathrm{Ca}^{2+}$-sensitive fluorescent indicator technique has made it possible to observe changes in $\left[\mathrm{Ca}^{2+}\right]_{i}$ and tension of intact vascular smooth muscle simultaneously. This technique has shown that vasoconstrictive receptor agonists such as phenylephrine ${ }^{6}$ and prostaglandin $\mathrm{F}_{2 \alpha}\left(\mathrm{PGF}_{2 \alpha}\right)^{7}$ increase $\mathrm{Ca}^{2+}$ sensitivity. To determine the normal $\mathrm{Ca}^{2+}$ sensitivity in the absence of receptor agonists, the $\mathrm{Ca}^{2+}$ ionophore, ionomycin or high $\mathrm{KCl}$ induced depolarization has been widely used because they introduce $\mathrm{Ca}^{2+}$ into the cytoplasm without acting on receptors. The $\mathrm{Ca}^{2+}$ sensitivity obtained with ionomycin is consistent with that obtained with the skinned fibre technique. ${ }^{8}$ However, some studies have demonstrated that high $\mathrm{KCl}$ produces stronger contraction than ionomycin in a range of $\left[\mathrm{Ca}^{2+}\right]_{\mathrm{i}}{ }^{8}$ This suggests that high $\mathrm{KCl}$-induced depolarization may also increase $\mathrm{Ca}^{2+}$ sensitivity. Therefore, ionomycin may be more suitable to determine the normal $\mathrm{Ca}^{2+}$ sensitivity than high $\mathrm{KCl}$.

Halothane decreases $\left[\mathrm{Ca}^{2+}\right]_{i}$ by reducing $\mathrm{Ca}^{2+}$ influx through $\mathrm{Ca}^{2+}$ channels across the sarcolemma. ${ }^{9}$ This suggests that the decrease in $\left[\mathrm{Ca}^{2+}\right]_{\mathrm{i}}$ may play a role in halothane-induced vasodilatation. Moreover, some studies using skinned fibre technique have shown that halothane may decrease $\mathrm{Ca}^{2+}$ sensitivity. In the rabbit aortic smooth muscle, halothane $3 \%$ does not change submaximum $\mathrm{Ca}^{2+}$-induced contraction but slightly decreases maximum $\mathrm{Ca}^{2+}$-induced contraction. ${ }^{10}$ In the rat mesenteric artery, halothane, $2 \%$ and $4 \%$, decreases submaximum and maximum $\mathrm{Ca}^{2+}$. induced contractions. ${ }^{11}$ These reports suggest that halothane may induce vasodilatation not only by the decrease in $\left[\mathrm{Ca}^{2+}\right]_{\mathrm{i}}$ but also by the decrease in $\mathrm{Ca}^{2+}$ sensitivity. However, the $\left[\mathrm{Ca}^{2+}\right]_{i}$-tension relationships in the absence and presence of halothane have not been compared directly. The first aim of this study is to determine whether halothane changes the normal $\left[\mathrm{Ca}^{2+}\right]_{i}$-tension relationship. The second aim is to determine whether halothane changes the $\mathrm{Ca}^{2+}$ sensitivity increased by high $\mathrm{KCl}$, phenylephrine or $\mathrm{PGF}_{2 \alpha}$.

\section{Methods}

\section{Tissue preparation and Fura PE3 loading}

The protocol was approved by the Kyoto University Animal Use Committee. Descending thoracic aortas were isolated from Wistar rats $(250-300 \mathrm{~g})$ anesthetized with $50 \mathrm{mg} \cdot \mathrm{kg}^{-1}$ sodium pentobarbital. The aortas were then cut into rings $2.5 \mathrm{~mm}$ wide, denuded of endothelia, and incubated with Fura PE3AM (10 $\mu$ M, Teflabs, Austin, TX, USA) for $6 \mathrm{~h}$ at $25^{\circ} \mathrm{C}$. Fura PE3-AM was dissolved in Cremophor EL $(0.02 \%$, Sigma Chemical Co., St Louis, MO, USA).

\section{Measurement of isometric tension}

Each aortic ring was mounted horizontally in an organ bath containing Krebs' solution $\left(7 \mathrm{ml}\right.$ at $\left.37^{\circ} \mathrm{C}\right)$ and connected to a strain gauge transducer (T7-240, Toyo Baldwin, Japan). The solution was gassed with an $\mathrm{O}_{2}$ $95 \% / \mathrm{CO}_{2} 5 \%$ gas mixture ( $\mathrm{pH} 7.4$ ). The aortic rings were equilibrated at the optimal resting tension of $1.5 \mathrm{~g}$ for $30 \mathrm{~min}$, while the fluorescent indicator that had not been taken up into the cells was rinsed out. Following equilibration, each aortic ring was contracted with phenylephrine $\left(\mathrm{EC}_{\max }=1 \mu \mathrm{M}\right.$, Sigma) or $\mathrm{PGF}_{2 \alpha}$ $\left(E C_{\max }=10 \mu \mathrm{M}\right.$, Ono Pharmaceutical Co., Tokyo, Japan). The absence of endothelium was confirmed by measuring the response to acetylcholine $(10 \mu \mathrm{M})$ in the aortic rings submaximally precontracted with phenylephrine $\left(\mathrm{EC}_{70}=100 \mathrm{nM}\right)$ or $\mathrm{PGF}_{2 \alpha}\left(\mathrm{EC}_{70}=1-3 \mu \mathrm{M}\right)$.

\section{Measurement of $\left[\mathrm{Ca}^{2+}\right]_{i}$}

The aortic rings were illuminated with ultraviolet light at 340 and $380 \mathrm{~nm}$ and the fluorescence elicited at $500 \mathrm{~nm}$ was monitored (as $\mathrm{F}_{340}$ and $\mathrm{F}_{380}$, respectively) continuously using a dual-wavelength fluorometer (CAF110, Japan Spectroscopic, Tokyo, Japan). ${ }^{12,13}$ Since the dissociation constant of a fluorescent dye for $\mathrm{Ca}^{2+}$ in cytoplasm is controversial, the ratio of $\mathrm{F}_{340}$ to $\mathrm{F}_{380}\left(\mathrm{~F}_{340} / \mathrm{F}_{380}\right.$ ratio) was used as an index of the $\left[\mathrm{Ca}^{2+}\right]_{i}{ }^{12,14-16}$ The resting level of tension and $\mathrm{F}_{340 / 380}$ ratio was regarded as $0 \%$ and the increase in tension and $\mathrm{F}_{340 / 380}$ ratio induced by $30 \mathrm{mM} \mathrm{KCl}$ was used as a reference value $(100 \%)$. Any contraction or increase in $\mathrm{F}_{340 / 380}$ ratio was expressed as a relative value (\%) to the reference value to normalize. ${ }^{12,14-16}$ The $\mathrm{F}_{340} / \mathrm{F}_{380}$ ratio and tension were measured simultaneously. 


\section{Delivery of balothane}

Halothane (Takeda Pharmaceutical Co, Osaka, Japan) was delivered with the $\mathrm{O}_{2} / \mathrm{CO}_{2}$ gas mixture through a vaporizer (Fluotec 3, Cyprane Keighley, England). The concentration of halothane in the gaseous phase was monitored and adjusted with an anesthetic gas monitor (Atom 303, Atom, Tokyo, Japan). The concentration of halothane in Krebs' solution was assayed by gas chromatography. ${ }^{12}$

\section{Experimental protocol}

In one series of experiments, ionomycin (10 nM-3 $\mu M$, Sigma) was added to normal Krebs' solution cumulatively to obtain the normal $\left[\mathrm{Ca}^{2+}\right]_{\mathrm{i}}$-tension relationship. Halothane $(1.5 \%$ or $3 \%$ ) was added to some aortic rings eight minutes before the cumulative addition of ionomycin.

In the other series of experiments, the aortic rings were treated with $\mathrm{Ca}^{2+}$-free Krebs' solution including the $\mathrm{Ca}^{2+}$ chelating agent, ethylene glycol bis (baminoethylether)-N,N,N',N'-tetraacetic acid (EGTA, $2 \mathrm{mM}$, Nacalai Tesque Co., Kyoto, Japan) for five minutes. Subsequently, the bathing solution was replaced by $\mathrm{Ca}^{2+}$-free Krebs' solution with EGTA $(0.3 \mathrm{mM})$. Thus, extracellular $\mathrm{Ca}^{2+}$ was removed. Two minutes after the replacement, $\mathrm{KCl}\left(\mathrm{EC}_{\max }=50 \mathrm{mM}\right)$, phenylephrine $\left(\mathrm{EC}_{70}=100 \mathrm{nM}\right)$ or $\mathrm{PGF}_{2 \alpha}\left(\mathrm{EC}_{70}=1-3 \mu \mathrm{M}\right)$ was applied. Eight minutes later, $\mathrm{CaCl}_{2}(0.3-3 \mathrm{mM})$ was given cumulatively to determine the $\left[\mathrm{Ca}^{2+}\right]_{\mathrm{i}}$-tension relationship in the presence of the vasoconstrictors. ${ }^{8}$ Halothane $(1.5 \%$ or $3 \%)$ was added to some aortic rings eight minutes before the cumulative addition of $\mathrm{CaCl}_{2}$. At the end of each experiment, the aortic rings were washed out with normal Krebs' solution to con- firm that the resting level of $\mathrm{F}_{340} / \mathrm{F}_{380}$ ratio and tension was stable. Because more than $3 \mathrm{mM} \mathrm{CaCl}$ affected the values of $\mathrm{F}_{340}$ and $\mathrm{F}_{380}$, up to $3 \mathrm{mM} \mathrm{CaCl}_{2}$ was used in this study.

Since the $\mathrm{Ca}^{2+}$ sensitivity changes time-dependently, ${ }^{17} \mathrm{~F}_{340} / \mathrm{F}_{380}$ ratio and tension were sampled at five minutes after the cumulative addition of ionomycin or $\mathrm{CaCl}_{2}$. In our preliminary experiment, the peak level of $\mathrm{F}_{340} / \mathrm{F}_{380}$ ratio had been achieved within five minutes.

\section{Solutions}

Krebs' solution comprised (mM) $\mathrm{NaCl}$ 127.5, $\mathrm{NaHCO}_{3}$ 15.5, glucose $10, \mathrm{KCl} 4.6, \mathrm{CaCl}_{2} 2.5$ $\mathrm{KH}_{2} \mathrm{PO}_{4} 1.2$ and $\mathrm{MgSO}_{4}$ 1.2. $\mathrm{Ca}^{2+}$-free solution was made by exclusion of $\mathrm{CaCl}_{2}$ from Krebs' solution. High $\mathrm{K}^{+}$solution was made by substituting $\mathrm{NaCl}$ with equivalent $\mathrm{KCl}$.

\section{Statistical analysis}

The data were expressed as means \pm SEM.. The $\mathrm{F}_{340} / \mathrm{F}_{380}$ ratio-tension relationships were compared statistically by a linear regression analysis. To fit data to a linear regression, the tail part of data where no contraction was observed was excluded. The slope and intercept values of linear regression were analyzed by one-way analysis of variance and Student's NeumanKeuls test to evaluate differences between groups. Differences at $P<0.05$ were considered significant statistically.

\section{Results}

Concentration of halothane in the batbing solution

The concentration of halothane used in this study ( $1.5 \%$ and $3 \%$ in the gaseous phase) equated to $0.37 \pm$

TABLE The effect of halothane on the regression line of $\mathrm{F}_{340} / \mathrm{F}_{380}$ - tension relationship in various conditions

\begin{tabular}{|c|c|c|c|c|}
\hline & Condition & & Slope & Intercept \\
\hline & Control & & $0.239 \pm 0.037$ & $-1.955 \pm 8.034$ \\
\hline \multirow{3}{*}{ lonomycin } & Halothane & $(1.5 \%)$ & $0.156 \pm 0.028$ & $7.391 \pm 5.049$ \\
\hline & Halothane & $(3 \%)$ & $0.110 \pm 0.010^{*}$ & $-3.463 \pm 2.343$ \\
\hline & Control & & $1.142 \pm 0.130$ & $10.623 \pm 8.234$ \\
\hline \multirow[t]{3}{*}{ High KCI } & Halothane & $(1.5 \%)$ & $0.857 \pm 0.161$ & $31.98 \pm 7.820$ \\
\hline & Halothane & $(3 \%)$ & $0.877 \pm 0.110$ & $11.340 \pm 5.475$ \\
\hline & Control & & $0.735 \pm 0.125$ & $44.024 \pm 4.593$ \\
\hline \multirow[t]{3}{*}{ Phenylephrine } & Halothane & $(1.5 \%)$ & $0.648 \pm 0.145$ & $43.363 \pm 4.593$ \\
\hline & Halothane & $(3 \%)$ & $0.884 \pm 0.168$ & $32.572 \pm 4.078$ \\
\hline & Control & & $0.902 \pm 0.140$ & $45.708 \pm 4.233$ \\
\hline \multirow[t]{2}{*}{$\mathrm{PGF}_{2 \alpha}$} & Halothane & $(1.5 \%)$ & $0.601 \pm 0.110$ & $40.715 \pm 4.247$ \\
\hline & Halothane & $(3 \%)$ & $0.532 \pm 0.078$ & $26.997 \pm 2.522 \dagger$ \\
\hline
\end{tabular}

Regression lines were calculated from data on ionomycin (100 $\mathrm{nM}-3 \mu \mathrm{M}), \mathrm{CaCl}_{2}(0.3-3 \mathrm{mM})$ in the presence of high $\mathrm{KCI}$ or phenylephrine and $\mathrm{CaCl}_{2}(0.6-3 \mathrm{mM})$ in the presence of $\mathrm{PGF}_{2 \alpha}$.

Values are mean $\pm S E M$. $n=20-70$.

$\star P<0.05$ and $\dagger P<0.01$ for control. 


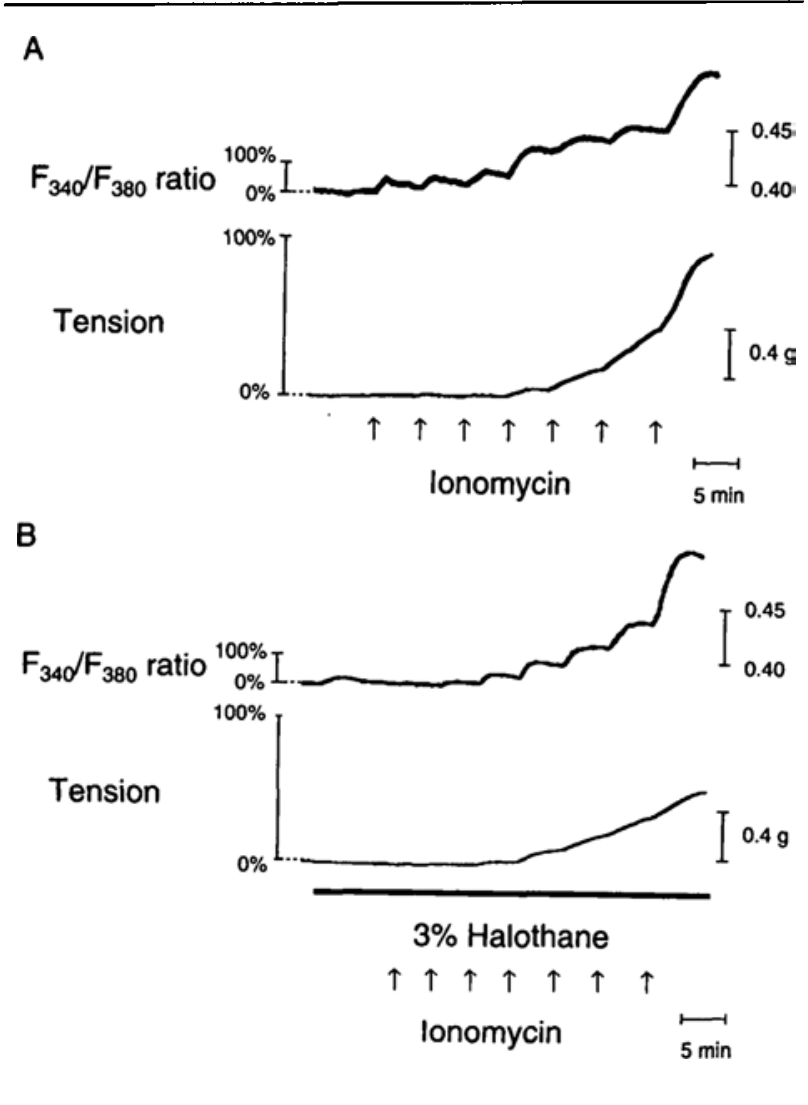

FIGURE 1 Typical recordings of the changes in $\mathrm{F}_{340} / \mathrm{F}_{380}$ ratio and tension obtained with the cumulative addition of ionomycin ( $10 \mathrm{nM}-3 \mu \mathrm{M}$, every five minutes, $\uparrow$ ) to normal Krebs' solution (control, A) and the effect of halothane (3\%) on the changes in $\mathrm{F}_{340} / \mathrm{F}_{380}$ ratio and tension (B).

$0.01 \mathrm{mM}$ and $0.79 \pm 0.01 \mathrm{mM}(\mathrm{n}=3$, each $)$, respectively, in Krebs' solution. These concentrations in Krebs' solution are approximately $80 \%$ of the theoretical concentrations determined by the Krebs' solutionair partition coefficient at $37^{\circ} \mathrm{C} .{ }^{18}$ Therefore, the concentrations of halothane used in this study were equivalent to 1 and 2 minimum alveolar concentration (MAC) in rats and clinically relevant. ${ }^{19}$

\section{Effect of halothane on $F_{340} / F_{380}$ ratio-tension relation-} ship obtained with ionomycin

Figure 1 shows typical recordings of the changes in $\mathrm{F}_{340} / \mathrm{F}_{380}$ ratio and tension produced by the cumulative addition of ionomycin $(10 \mathrm{nM}-3 \mu \mathrm{M})$ in the presence and absence of halothane. The $\mathrm{F}_{340} / \mathrm{F}_{380}$ ratio-tension relationship obtained with ionomycin in the absence and presence of halothane are summarized as Figure 2. Although halothane (1.5\%) did not change the $\mathrm{F}_{340} / \mathrm{F}_{380}$ ratio-tension relationship,

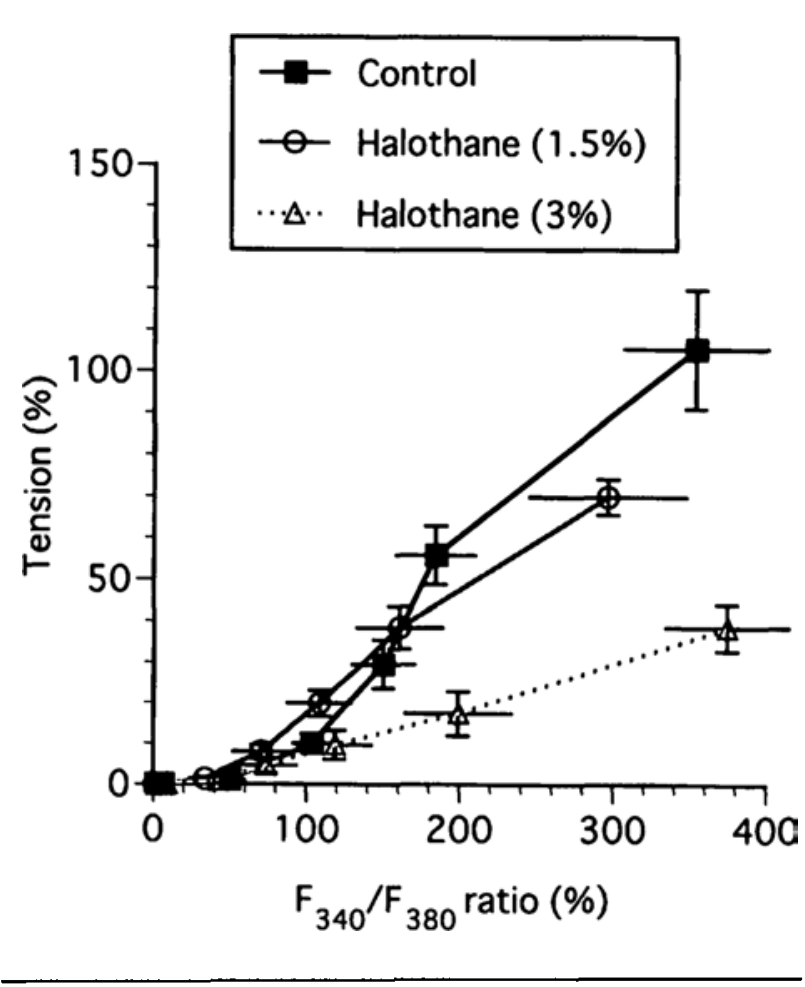

FIGURE 2 The normal $F_{340} / F_{380}$ ratio-tension relationship obtained with the cumulative addition of ionomycin (10 nM-3 $\mu \mathrm{M}$ ) to normal Krebs' solution (control) and the effect of halothane $(1.5 \%$ and $3 \%)$ on the relationship. Values are mean \pm SEM, $\mathrm{n}=7-9$.

halothane, $3 \%$, decreased the slope of the relationship $(P<0.05$, Table $)$.

Effect of halothane on $F_{340} / F_{380}$ ratio-tension relationship in the presence of high $K C l$, phenylephrine or $P G F_{2 \alpha}$ Figure 3 shows typical recordings of the changes in $\mathrm{F}_{340} / \mathrm{F}_{380}$ ratio and tension produced by the cumulative addition of $\mathrm{CaCl}_{2}(0.3-3 \mathrm{mM})$ in the presence of high $\mathrm{KCl}(50 \mathrm{mM})$ and the effect of halothane. The $\mathrm{F}_{340} / \mathrm{F}_{380}$ ratio-tension relationship in the presence of high $\mathrm{KCl}$, phenylephrine or $\mathrm{PGF}_{2 \alpha}$ obtained with $\mathrm{CaCl}_{2}$ and the effect of halothane on the relationship are summarized in Figures 4,6.

The $\mathrm{Ca}^{2+}$ sensitivity in the absence of halothane was, in order, phenylephrine $=\mathrm{PGF}_{2 \alpha}>$ high $\mathrm{KCl}>$ ionomycin $(P<0.05$, Figures $2,4-6$, Table). There was no difference in the maximum values of tension between ionomycin, high $\mathrm{KCl}$, phenylephrine and PGF $_{2 \alpha}$ (Figures 2, 4-6).

To assess the effect of halothane on the $\mathrm{Ca}^{2+}$ sensitivity in the presence of high $\mathrm{KCl}$, phenylephrine or $\mathrm{PGF}_{2 \alpha}$ statistically, the data obtained with $\mathrm{CaCl}_{2}$ (0.3- 


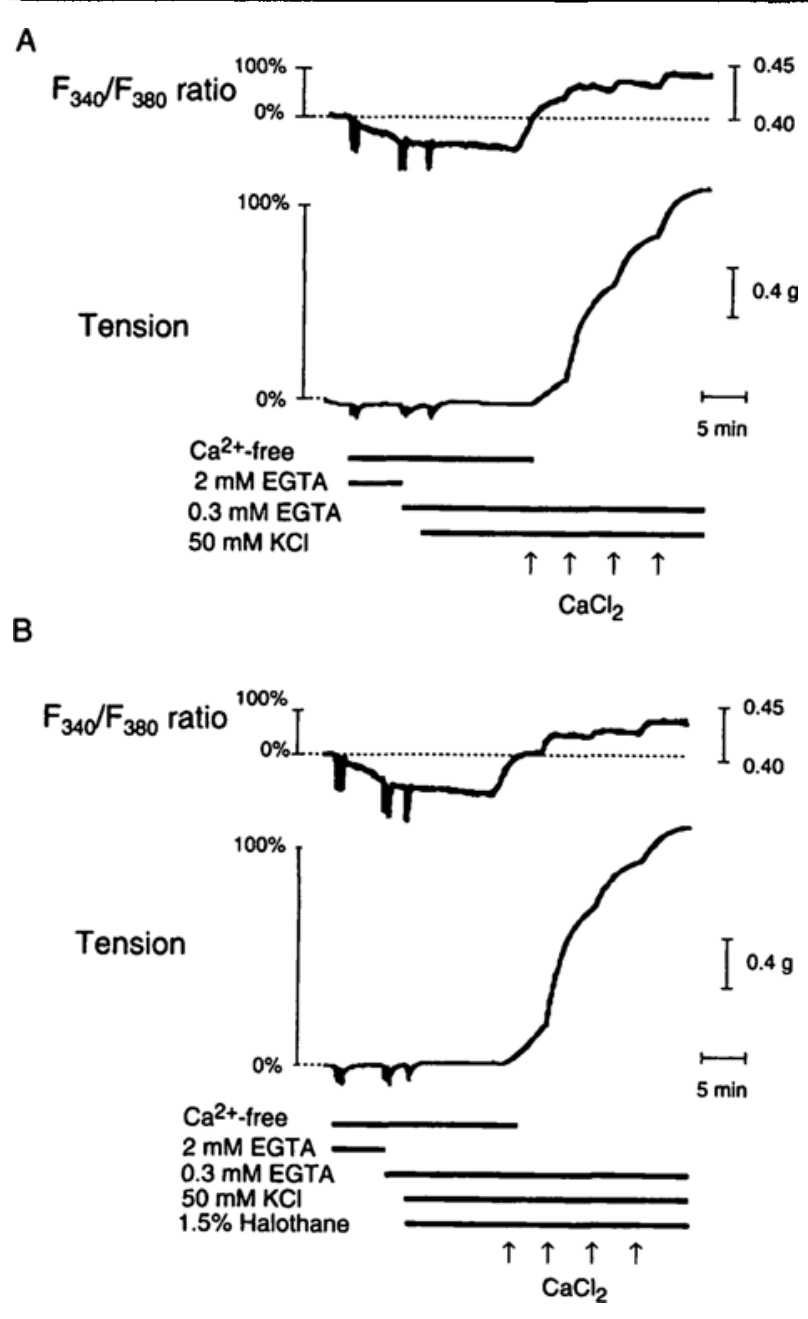

FIGURE 3 Typical recordings of the changes in $\mathrm{F}_{340} / \mathrm{F}_{380}$ ratio and tension obtained with the cumulative addition of $\mathrm{CaCl}_{2}(0.3-3$ $\mathrm{mM}$, every $5 \mathrm{~min}, \uparrow$ ) to $\mathrm{Ca}^{2+}$-free Krebs' solution in the presence of $50 \mathrm{mM} \mathrm{KCl}$ (control, A) and the effect of halothane (1.5\%) on the changes in $\mathrm{F}_{340} / \mathrm{F}_{380}$ ratio and tension (B).

$3 \mathrm{mM})$ in the presence of high $\mathrm{KCl}$ or phenylephrine and the data obtained with $\mathrm{CaCl}_{2}(0.6-3 \mathrm{mM})$ in the presence of $\mathrm{PGF}_{2 \alpha}$ were also fitted to linear regression and analyzed (Table). Halothane (1.5\% and $3 \%$ ) did not change the $\mathrm{F}_{340} / \mathrm{F}_{380}$ ratio-tension relationship in the presence of high $\mathrm{KCl}$ (Figure 4, Table). Neither did halothane $\left(1.5 \%\right.$ and $3 \%$ ) change the $\mathrm{F}_{340} / \mathrm{F}_{380}$ ratio-tension relationship in the presence of phenylephrine (Figure 5, Table). In contrast, although halothane $(1.5 \%)$ did not affect the $\mathrm{F}_{340} / \mathrm{F}_{380}$ ratiotension relationship in the presence of $\mathrm{PGF}_{2 \alpha}$, halothane $(3 \%)$ showed the inhibitory effect on the relationship $(P<0.01$, Figure 6 , Table $)$.

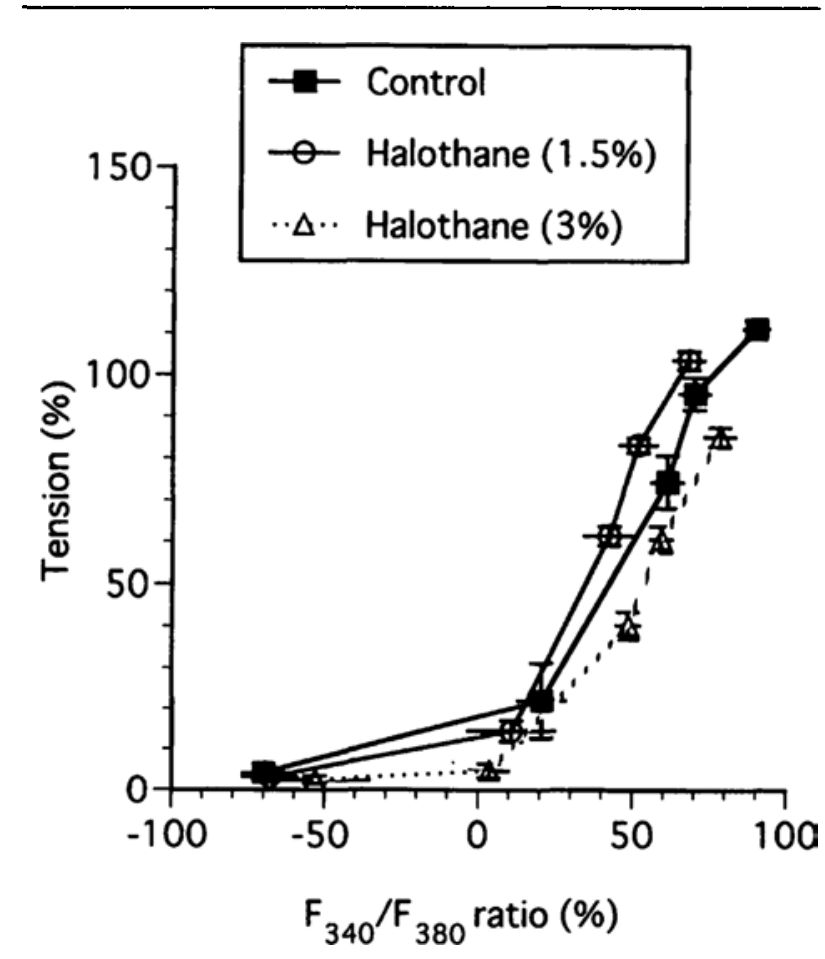

FIGURE 4 The $\mathrm{F}_{340} / \mathrm{F}_{380}$ ratio-tension relationship obtained with the cumulative addition of $\mathrm{CaCl}_{2}(0.3-3 \mathrm{mM})$ to $\mathrm{Ca}^{2+}$-free Krebs' solution in the presence of $50 \mathrm{mM} \mathrm{KCl}$ (control) and the effect of halothane (1.5\% and $3 \%$ ) on the relationship. Values are mean $\pm S E M, n=6$.

\section{Discussion}

The present study has shown that halothane (3\%) strongly suppresses the normal $\left[\mathrm{Ca}^{2+}\right]_{i}$-tension relationship obtained with ionomycin. Our study has also demonstrated the inhibitory effect of halothane (3\%) on the $\left[\mathrm{Ca}^{2+}\right]_{i}$-tension relationship in the presence of $\mathrm{PGF}_{2 \alpha}$ in contrast to the results of high $\mathrm{KCl}$ and phenylephrine. These results suggest that the inhibitory effect on the $\mathrm{Ca}^{2+}$ sensitivity may be an important mechanism of halothane-induced vasodilatation.

The fluorescent $\mathrm{Ca}^{2+}$ indicator used in this study, Fura PE3, is a derivative of the well-known fluorescent $\mathrm{Ca}^{2+}$ indicator, Fura 2. We used Fura PE3 because Fura PE3 leaks out of cells less than Fura 2 and can therefore be used for prolonged observations of $\left[\mathrm{Ca}^{2+}\right]_{i}$.

The $\left[\mathrm{Ca}^{2+}\right]_{\mathrm{i}}$-tension relationship is usually a nonlinear curve. A conventional approach to analyze the $\left[\mathrm{Ca}^{2+}\right]_{\mathrm{i}}$-tension relationship is the logistic model. To use the logistic regression model, the ceiling values of tension (maximum contraction) is essential. However, we could not confirm whether contraction induced by the last concentration of $\mathrm{CaCl}_{2}$ used in this study was 


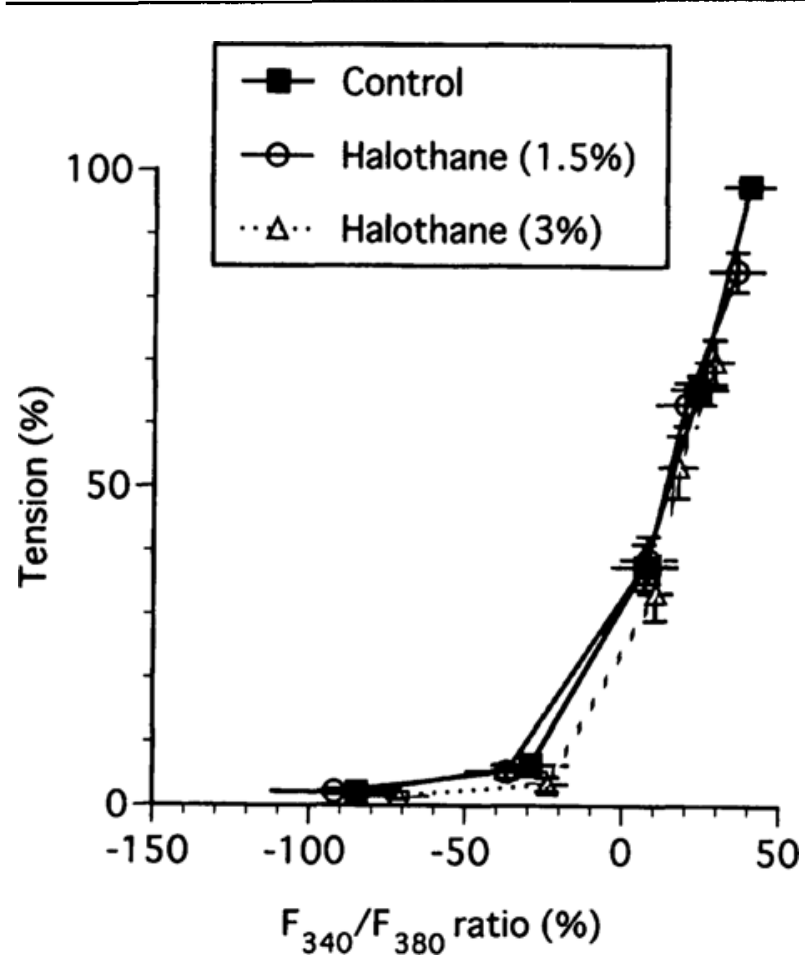

FIGURE 5 The $\mathrm{F}_{340} / \mathrm{F}_{380}$ ratio-tension relationship obtained with the cumulative addition of $\mathrm{CaCl}_{2}(0.3-3 \mathrm{mM}$, every five minutes) to $\mathrm{Ca}^{2+}$-free Krebs' solution in the presence of phenylephrine $(100 \mathrm{nM}$, control) and the effect of halothane (1.5\% and $3 \%)$ on the relationship. Values are mean $\pm S E M, n=5-7$.

the maximum contraction because higher concentration of $\mathrm{CaCl}_{2}$ affected the measurement of $\mathrm{F}_{340} / \mathrm{F}_{380}$ ratio (see method). Another approach is a linear regression model, because the slope of a logistic curve is almost linear. Therefore, we excluded the tail part of the data where no contraction was developed and analyzed the slope part by using linear regression. The ordinate intercept is a statistical index to compare linear regression, but it must be interpreted with care. If the intercept is a positive value but data are distributed to the right of the axis of ordinate, we cannot say that contraction can be produced when $\left[\mathrm{Ca}^{2+}\right]_{i}$ is lower than the resting level. However, in the case of linear regression in the presence of phenylephrine or $\mathrm{PGF}_{2 \alpha}$, the intercept had a positive value and some data were distributed to the left of the ordinate axis. This result suggests that phenylephrine or $\mathrm{PGF}_{2 \alpha}$ may produce contraction when $\left[\mathrm{Ca}^{2+}\right]_{i}$ is lower than the resting level. This is consistent with some previous reports ${ }^{7,16}$ and supports the hypothesis that phenylephrine and $\mathrm{PGF}_{2 \alpha}$ increase $\mathrm{Ca}^{2+}$ sensitivity.

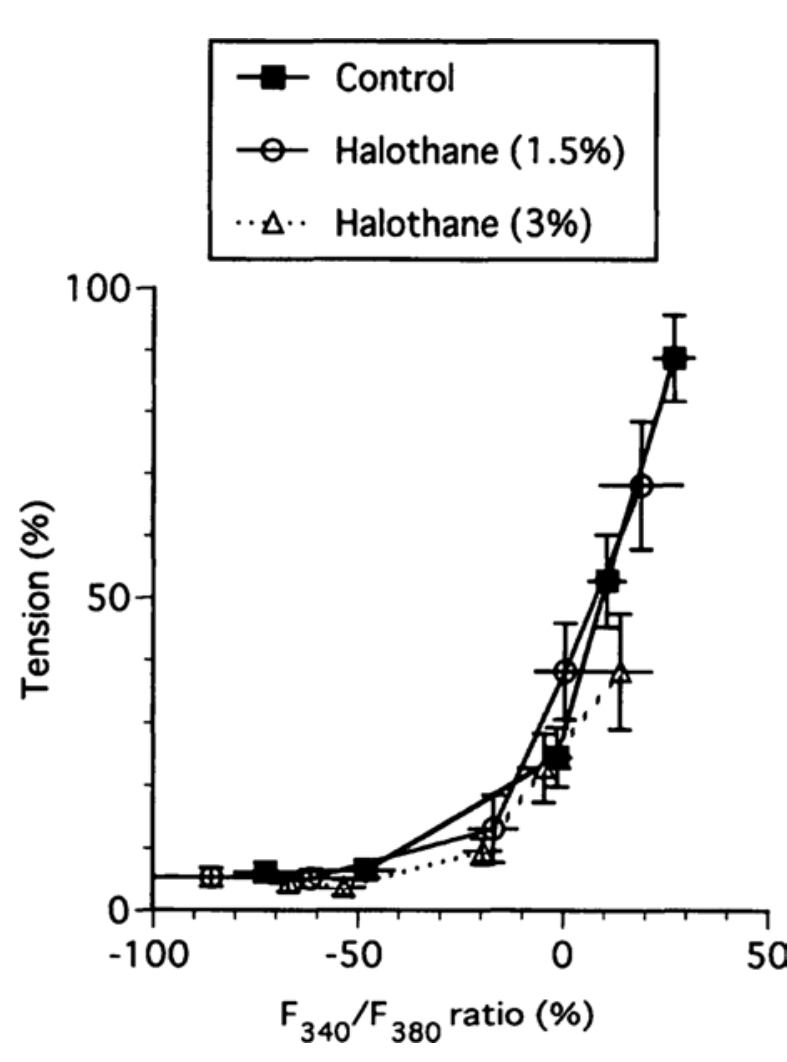

FIGURE 6 The $\mathrm{F}_{340} / \mathrm{F}_{380}$ ratio-tension relationship obtained with the cumulative addition of $\mathrm{CaCl}_{2}(0.3-3 \mathrm{mM})$ to $\mathrm{Ca}^{2+}$-free Krebs' solution in the presence of $\mathrm{PGF}_{2 a}(1-3 \mu \mathrm{M}$, control $)$ and the effect of halothane ( $1.5 \%$ and $3 \%)$ on the relationship. Values are mean $\pm S E M, n=6$.

Our study has shown that halothane $(3 \%)$ reduces the slope of normal $\left[\mathrm{Ca}^{2+}\right]_{i}$-tension relationship obtained with ionomycin. This suggests that halothane (3\%) can decrease the normal $\mathrm{Ca}^{2+}$ sensitivity. In contrast to the result of ionomycin, we could not find an inhibitory effect of halothane (3\%) on $\mathrm{Ca}^{2+}$ sensitivity in the presence of high $\mathrm{KCl}$. Our study suggested that the $\mathrm{Ca}^{2+}$ sensitivity in the presence of high $\mathrm{KCl}$ may be higher than the normal $\mathrm{Ca}^{2+}$ sensitivity obtained with ionomycin. This result supports the previous reports that high $\mathrm{KCl}$-induced depolarization may increase the $\mathrm{Ca}^{2+}$ sensitivity. ${ }^{8}$ Therefore, the effect of depolarization may mask that of halothane. However, because our experimental protocols for ionomycin and high $\mathrm{KCl}$ were different, further study will be needed to understand the different effects of halothane.

Our results showed that the $\mathrm{Ca}^{2+}$ sensitivity in the presence of phenylephrine or $\mathrm{PGF}_{2 \alpha}$ is higher than that in the presence of high $\mathrm{KCl}$. This is consistent with the 
previous reports that the vasoconstrictive receptor agonists increase the $\mathrm{Ca}^{2+}$ sensitivity. ${ }^{6,7}$ Interestingly, statistical analysis of the $\left[\mathrm{Ca}^{2+}\right]_{i}$-tension relationships demonstrated that halothane $(3 \%)$ decreases the $\mathrm{Ca}^{2+}$ sensitivity in the presence of $\mathrm{PGF}_{2 \alpha}$ whilst halothane (3\%) does not change $\mathrm{Ca}^{2+}$ sensitivity in the presence of phenylephrine. This suggests that the effect of halothane on $\mathrm{Ca}^{2+}$ sensitivity may depend on the stimulated receptor type. Phenylephrine and $\mathrm{PGF}_{2 \alpha}$ bind to $\alpha_{1}$ and FP receptors, respectively. Stimulation of $\alpha_{1}$ and FP receptors induces $\mathrm{IP}_{3}$ generation and increase in $\left[\mathrm{Ca}^{2+}\right]_{\mathrm{i}}$. Moreover, the stimulation of $\alpha_{1}$ receptor activates protein kinase $\mathrm{C}$ and increases the $\mathrm{Ca}^{2+}$ sensitivity. ${ }^{20,21}$ However, it is still unclear how stimulation of FP receptor increases $\mathrm{Ca}^{2+}$ sensitivity. A recent study suggests that the $\alpha_{1}$ and FP receptors may have different signal transduction pathways to increase the $\mathrm{Ca}^{2+}$ sensitivity. The study has shown that protein kinase $\mathrm{C}$ may not be involved in FP receptor stimulation-induced increase in the $\mathrm{Ca}^{2+}$ sensitivity. ${ }^{16}$ This may explain the different effects of halothane. Another possible explanation is that halothane may affect the binding affinity of PGF $_{2 \alpha}$ for the FP receptor but not affect the affinity of phenylephrine for the $\alpha_{1}$ receptor. We have demonstrated that in human platelets, a high concentration of halothane strongly suppresses the binding affinity of thromboxane $\mathrm{A}_{2}$ for its receptor. ${ }^{22}$ However, the effect of halothane on the binding affinity of $\mathrm{PGF}_{2 \alpha}$ for the FP receptor in the vascular smooth muscle has not been determined.

It is known that halothane inhibits $\mathrm{PGF}_{2 \alpha}$-induced contraction more than that produced by phenylephrine. ${ }^{23}$ Our results may contribute to explaining this and have clinical relevance. Production of PGF $_{2 \alpha}$ increases in intrauterine tissues during parturition and an increase in $\mathrm{PGF}_{2 \alpha}$ occurs in maternal plasma ${ }^{24}$ $\mathrm{PGF}_{2 \alpha}$ induces not only myometrial contraction but also contraction of the uterine artery. ${ }^{25}$ Therefore, our results may help to explain why obstetric anesthesia with halothane depresses the myometrial contraction and reduces the vascular resistance in the uterus.

To circumvent the problem with time-dependent change in the $\mathrm{Ca}^{2+}$ sensitivity, our data were sampled at a constant time (five minutes) after the cumulative addition of ionomycin or $\mathrm{CaCl}_{2}$. Therefore, in some experiments, tension was still developing slowly although the peak level of $\mathrm{F}_{340} / \mathrm{F}_{380}$ ratio had been achieved. This can cause underestimate of the $\mathrm{Ca}^{2+}$ sensitivity in the absence of halothane and make it difficult to detect a subtle change in the $\mathrm{Ca}^{2+}$ sensitivity in the presence of halothane. This may be one of the reasons why we could not find the significant decrease in the $\mathrm{Ca}^{2+}$ sensitivity in the presence of halothane in some series of experiment.
In conclusion, our study has suggested that the inhibitory effect of halothane on the $\mathrm{Ca}^{2+}$ sensitivity may contribute to the relaxation of rat aortic smooth muscle contracted with ionomycin or $\mathrm{PGF}_{2 \alpha}$.

\section{References}

1 Sprague DH, Yang JC, Nagai SH. Effects of isoflurane and halothane on contractility and cyclic 3',5'-adenosine monophosphate system in the rat aorta. Anesthesiology 1974; 40: 162-7.

2 Clark SC, MacCannell KL. Vascular responses to an aesthetic agents. Can Anaesth Soc J 1975; 22: 20-33.

3 Seyde WC, Longnecker DE. Anesthetic influences on regional hemodynamics in normal and hemorrhaged rats. Anesthesiology 1984; 61: 686-98.

4 Palabniuk RJ, Shnider SM. Maternal and fetal cardiovascular and acid-base changes during halothane and isoflurane anesthesia in the pregnant ewe.

Anesthesiology 1974; 41: 462-72.

5 Jobnson $D$, Mayers $I, T o T$. The effects of halothane in hypoxic pulmonary vasoconstriction. Anesthesiology 1990; 72: 125-33.

6 DeFeo TT, Morgan KG. Calcium-force relationships as detected with aequorin in two different vascular smooth muscles of the ferret. J Physiol (Lond) 1985; 369: 269-82.

7 Hori $M$, Sato $K$, Sakata $K$, et al. Receptor agonists induce myosin phosphorylation-dependent and phosphorylation-independent contractions in vascular smooth muscle. J Pharmacol Exp Ther 1992; 261: 506-12.

8 Bruschi G, Bruschi ME, Regolisti G, Borghetti $A$. Myoplasmic $\mathrm{Ca}^{2+}$-force relationship studied with fura-2 during stimulation of rat aortic smooth muscle. Am J Physiol 1988; 254: H840-54.

9 Buljubasic N, Rusch NJ, Marijic J, Kampine JP, Bosnjak ZJ. Effects of halothane and isoflurane on calcium and potassium channel currents in canine coronary arterial cells. Anesthesiology 1992; 76: 990-8.

10 Su $N$, Zhang CC. Intracellular mechanisms of halothane's effect on isolated aortic strips of the rabbit. Anesthesiology 1989; 71: 409-17.

11 Akata T, Boyle WA III. Volatile anesthetic actions on contractile proteins in membrane-permeabilized small mesenteric arteries. Anesthesiology 1995; 82: 700-12.

12 Kakuyama $M$, Hatano $\Upsilon$, Nakamura $K$, et al. Halothane and enflurane constrict canine mesenteric arteries by releasing $\mathrm{Ca}^{2+}$ from intracellular $\mathrm{Ca}^{2+}$ stores. Anesthesiology 1994; 80: 1120-7.

13 Kitamura R, Kakuyama M, Nakamura K, Miyawaki I, Mori $K$. Thiobarbiturates suppress depolarizationinduced contraction of vascular smooth muscle without suppression of calcium influx. Br J Anaesth 1996; 77 : 503-7. 
14 Himpens $B$, Somlyo $A P$. Free-calcium and force transients during depolarization and pharmacomechanical coupling in guinea-pig smooth muscle. J Physiol (Lond) 1988; 395: 507-30.

15 Sato $K$, Ozaki $H$, Karaki $H$. Changes in cytosolic calcium level in vascular smooth muscle strip measured simultaneously with contraction using fluorescent calcium indicator fura 2. J Pharmacol Exp Ther 1988; 246: 294-300.

16 Kurata R, Takayanagi I, Hisayama T. Eicosanoidinduced $\mathrm{Ca}^{2+}$ release and sustained contraction in $\mathrm{Ca}^{2+}$ free media are mediated by different signal transduction pathways in rat aorta. $\mathrm{Br} \mathrm{J}$ Pharmacol 1993; 110: 875-81.

17 Fukuizumi $\Upsilon$, Kobayashi S, Nishimura J, Kanaide $H$. Cytosolic calcium concentration-force relation during contractions in the rabbit femoral artery: time-dependency and stimulus specificity. Br J Pharmacol 1995; 114: 329-38.

18 Renzi F, Waud BE. Partition coefficients of volatile anesthetics in Krebs' solution. Anesthesiology 1977; 47: 62-3.

19 White PF, Jobnston RR, Eger EI II. Determination of anesthetics requirement in rats. Anesthesiology 1974; 40: 52-7.

20 Bylund DB, Eikenberg DC, Hieble JP, et al. International union of pharmacology nomenclature of adrenoceptors. Pharmacol Rev 1994; 46: 121-36.

21 Coleman RA, Smith WL, Narumiya S. International union of pharmacology classification of prostanoid receptors: properties distribution, and structure of the receptors and their subtypes. Pharmacol Rev 1994; 46: 205-29.

22 Hirakata $H$, Ushikubi $F$, Narumiya $S$, Hatano $Y$, Nakamura $K$, Mori $K$. The effect of inhaled anesthetics on the platelet aggregation and the ligand-binding affinity of the platelet thromboxane $A_{2}$ receptor. Anesth Analg 1995; 81 : 114-8.

23 Yamamoto $M$, Hatano $\Upsilon$, Kakuyama $M$, et al. Halothane and isoflurane preferentially inhibit prostanoid-induced vasoconstriction of rat aorta. Can J Anaesth 1994; 41: 991-5.

24 Olson DM, Lye SJ, Skinner K, Challis JRG. Prostanoid concentrations in maternal/fetal plasma and amniotic fluid and intrauterine tissue prostanoid output in relation to myometrial contractility during the onset of adrenocorticotropin-induced preterm labor in sheep. Endocrinology 1985; 116: 389-97.

25 Grbovi L, Jovanovi A, Tuli I. Indomethacin reduces contraction of isolated non-pregnant human uterine artery induced by prostaglandin $\mathrm{F}_{2 \alpha}$. Hum Reprod 1996; 11 : 1998-2002. 